\title{
SUCCESS OF SEVERITY LEVEL II AND III CASE MANAGEMENT AMONG OBSTETRICS AND GYNECOLOGY PATIENTS AT HASAN SADIKIN GENERAL HOSPITAL, BANDUNG, WEST JAVA
}

\author{
Windi Nurdiawan, Zulvayanti , Dini Hidayat, Hadi Susiarno, Dini \\ Pusianawati, Fadhilah Zulfa \\ Departement of Obstetrics and Gynecology, Dr. Hasan Sadikin Hospital, \\ Universitas Padjadjaran
}

\begin{abstract}
Background: The evaluation of maternal condition and selection of the high-risk obstetrics and gynecology patients that requires high level of cares are essential in order to reduce its morbidity and mortality. Recently, various studies focus on the importance of evaluation for maternal conditions and allocation of high risk obstetrics and gynecology patients to highly qualified facilities. This study aimed to describe the success of severity level II and III case management among obstetrics and gynecology patients at Hasan Sadikin General Hospital, Bandung, West Java.

Subjects and Method: This was a cross sectional study conducted at Hasan Sadikin General Hospital, Bandung, West Java. A total of 4084 obstetric and gynecology patients with severity level II and III was selected for this study. The data of obstetrics and gynecology patient were obtained from medical record. The data was measured by the outcome of discharge patients compare with outcome indicators in hospital. The data were analyzed descriptively.

Results: 2468 of 2504 (98.56) obstetrics patients had severity level II. 172 of 188 (91.49\%) had severity level III. 970 of 1066 (90.99\%) gynecology patients had severity level II. 228 of 326 (69.94\%) had severity level III.

Conclusion: The best outcomes achieved on obstetrics patients with severity level II. Improving and maintaining quality care of obstetrics and gynecology patients is required.
\end{abstract}

Keywords: obstetrics, gynecology, severity level

\section{Correspondence:}

Windi Nurdiawan. Departement of Obstetrics and Gynecology, Dr. Hasan Sadikin Hospital, Universitas Padjadjaran, Bandung, West Java, Indonesia.

Email: windi@unpad.ac.id. Mobile: (+6222)2032530.

The 5th International Conference on Public Health Best Western Premier Hotel, Solo, Indonesia, February 13-14, 2019 | 322

https://doi.org/10.26911/theicph.2019.03.51 